\begin{tabular}{|c|c|}
\hline Title & 2-(p-Nitrophenyl)-2 -deoxyadenosine, a new type of mutagenic nucleoside \\
\hline Author(s) & $\begin{array}{l}\text { Matsuda, A kira; Ohara, Y oshiko; Kakutani, Toshifumi; Negishi, Kazuo; W atay a, Y usuke; Hay atsu, Hikoya; Ueda, } \\
\text { Tohru }\end{array}$ \\
\hline Citation & $\begin{array}{l}\text { Nucleic A cids Research, } 18(7), 1833-1838 \\
\text { https://doi.org/10.1093/har/18.7.1833 }\end{array}$ \\
\hline Issue Date & 1990-04 \\
\hline Doc URL & http:/hdl.handle.net/2115/46969 \\
\hline Type & article \\
\hline File Information & 73_90 NA R 2-NO2Ph-dA do.pdf \\
\hline
\end{tabular}

Instructions for use 


\title{
2-(p-Nitrophenyl)-2'-deoxyadenosine, a new type of mutagenic nucleoside
}

\author{
Akira Matsuda*, Yoshiko Ohara ${ }^{1}$, Toshifumi Kakutani ${ }^{1}$, Kazuo Negishi ${ }^{1}$, Yusuke Wataya ${ }^{1}$, Hikoya \\ Hayatsu ${ }^{\top}$ and Tohru Ueda \\ Faculty of Pharmaceutical Sciences, Hokkaido University, Kita-12, Nishi-6, Kita-ku, Sapporo 060 and \\ ${ }^{1}$ Faculty of Pharmaceutical Sciences, Okayama University, Tsushimanaka 1-1-1, Okayama 700, Japan
}

Received November 28, 1989, Revised and Accepted January 4, 1990

\begin{abstract}
A crude preparation of 2-phenyladenosine was found to be mutagenic in the Ames Salmonella assay. In the purification of this preparation, it was revealed that 2-phenyladenosine itself was nonmutagenic but that 2-( $m$ - and $p$-nitrophenyl)-adenosines $(5 \mathrm{~m}, \mathrm{p})$ contaminating the sample were the mutagenic principles. A structure-activity relationship study was carried out, and it was found that 5p, 2-(p-nitrophenyl)adenine (7p), and 2-(p-nitrophenyl)-2'-deoxyadenosine (15p) were strongly mutagenic toward $S$. typhimurium TA98 and TA100 without metabolic activation, the potency being in the order $15 p>7 p>5 p$. The potency of 15p in TA98 was one order of magnitude greater than that of 4-nitroquinoline $\mathrm{N}$-oxide. 15p also showed mutagenicity in the mouse cell line FM3A in culture.
\end{abstract}

\section{INTRODUCTION}

Some nucleosides such as 5-bromodeoxyuridine ${ }^{2}, \mathrm{~N}^{4}$-hydroxycytidine ${ }^{3-5}$, and $\mathrm{N}^{4}$-aminocytidine ${ }^{6}$, and nucleobases such as 2-aminopurine ${ }^{2}$ and 2-amino-6-hydroxyaminopurine ${ }^{7}$ have been known to be mutagenic. Most of these compounds act actually as promutagens. By cellular metabolism, these compounds are converted into corresponding 2'-deoxynucleoside 5 '-triphosphates, which would be incorporated into DNA chains during replication and induce mutations. Elucidation of the mechanism of these phenomena is important for understanding mutagenesis and even carcinogenesis.

We have tested about 100 modified nucleosides for mutagenicity by the reversion of histidine dependent Salmonella system (Salmonella typhimurium TA98 for detection of mutagens causing frameshifts and TA100 for those causing base-pair

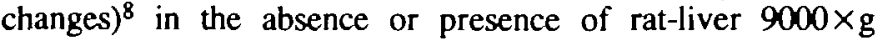
supernatant fraction (S9). Among these nucleoside derivatives, we have found a crude preparation of 2-phenyladenosine (3) to be mutagenic to TA98 as well as TA100 without metabolic activation by S9. This nucleoside was synthesized ${ }^{9}$ by the route shown in scheme 1. 2-Amino-6-chloropurine riboside (1) was treated with an excess of isopentyl nitrite in benzene in the presence of copper(I) oxide to afford a 6-chloro-2-phenylpurine riboside (2). The crude product of 2 was then heated with methanolic ammonia in a sealed tube at $70^{\circ}$ to give a crude 3 . We describe here the structure determination of the minor mutagenic products in this sample and the results of studies on the structure-activity relationship of the mutagenicity. Preliminary accounts of this work have appeared ${ }^{10,11}$.

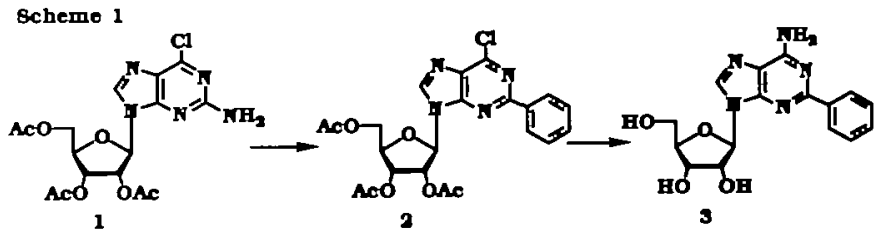

\section{RESULTS and DISCUSSION}

In order to determine the chemical structure of the mutagenic compounds, the crude sample was purified with high performance liquid chromatography (HPLC) using a reverse phase column (Fig.1). The purified 2-phenyladenosine (3; peak 1) showed no mutagenicity in TA98 and TA100. Instead, the mutagenic activity toward both strains was almost entirely concentrated in one of the minor peaks (peak 3 ), which seemed to consist of more than one compound. From about $200 \mathrm{mg}$ of crude $3,0.8 \mathrm{mg}$ of a mixture of the minor nucleosides was isolated by using a semipreparative column. The ${ }^{1} \mathrm{H}-\mathrm{NMR}$ spectra of this sample from peak 3 showed that the mixture consisted of at least two components and the phenyl ring at the 2-position of adenine moiety was mono-substituted (Fig.2). Mass spectral data of this material showed a molecular ion peak at $\mathrm{m} / \mathrm{z} 388$; the number corresponding to the molecular weight of 2-phenyladenosine minus 1 plus $\mathrm{NO}_{2}$ (46). From these results, the compounds of peak 3 appeared to be a mixture of isomeric 2-(nitrophenyl)adenosines.

To determine the position of the nitro group in the phenyl ring, we synthesized 2-(o-, $\mathbf{m}$ - and $p$-nitrophenyl)-adenosines $(\mathbf{5 0}, \mathbf{m}, \mathbf{p})$ in an unambiguous manner ${ }^{12}$. Treatment of 4-cyano-5-aminoimidazole riboside $(4)^{11}$, which was obtained 


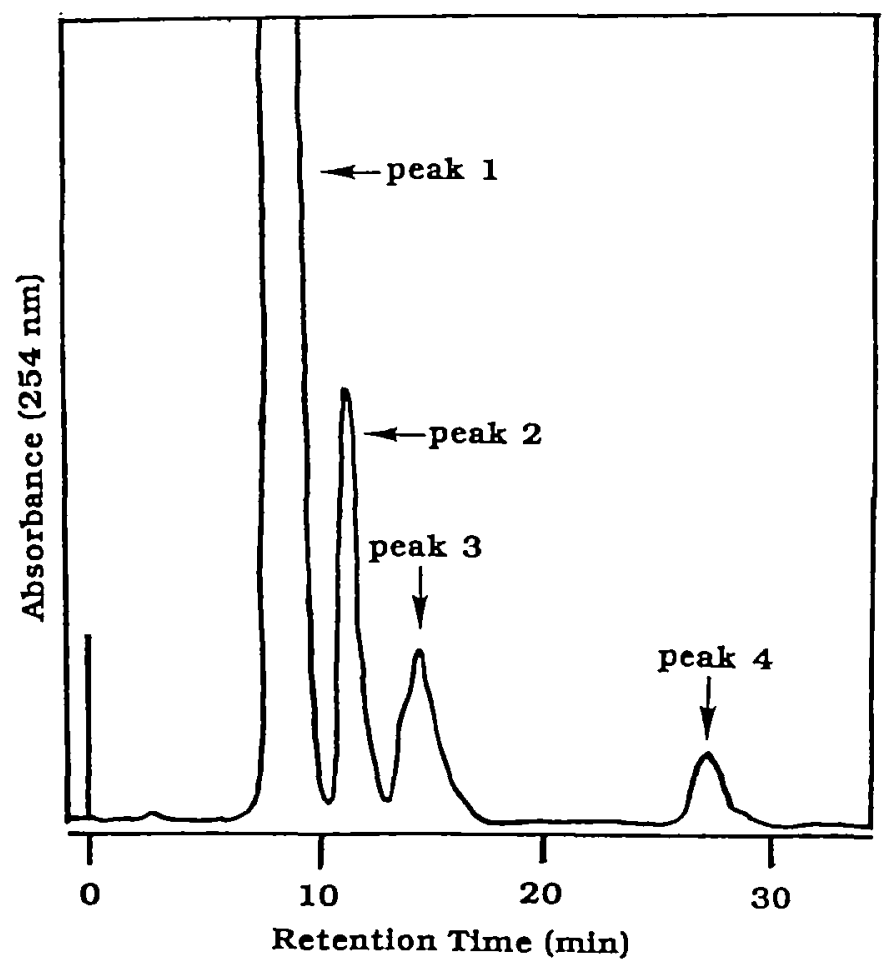

Figure 1. HPLC chromatogram of the crude sample of 3 Retention times of peak $1,2,3$, and 4 were $8.2,11.3,14.3$, and $27.1 \mathrm{~min}$, respectively. readily from commercially available 5-aminoimidazole-4-carboxamide riboside in two steps, with $o-, m-$, or $p$-nitrobenzonitriles in methanolic ammonia using a steel tube at $170^{\circ}$, afforded desired 2- $(o-, m$-, or $p$-nitrophenyl)-adenosines $(\mathbf{5 0}, \mathbf{m}$, and $\mathbf{p})$ in yields of 20,51, and 71\%, respectively (Scheme 2$)$. The 2-( $m$ and $p$-njtrophenyl)-adenosines ( $5 \mathrm{~m}$ and $\mathrm{p}$ ) showed retention times (13.7 and $14.0 \mathrm{~min}$, respectively) almost the same as that of peak 3 (14.3 min). The retention time of 2-(o-nitrophenyl)-adenosine (50) was found to be very short $(4.7 \mathrm{~min})$. ' $\mathrm{H}$-NMR spectral data (the aromatic region) of peak 3 and other derivatives are shown in Fig. 2 and it is evident that peak 3 contains $5 \mathrm{~m}$ and $5 p$ in a ratio of $1: 3$.
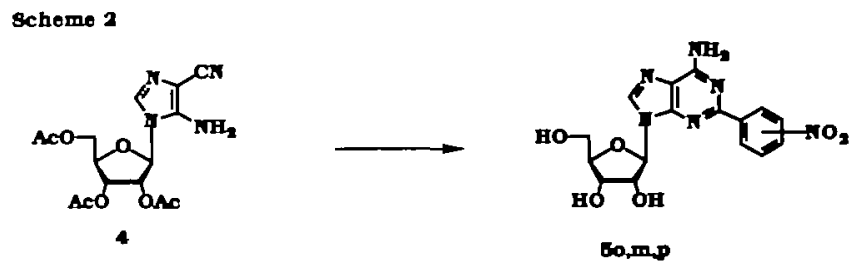

We next examined the mutagenic activity of these nucleosides. Both $5 \mathrm{~m}$ and $5 \mathrm{p}$ showed mutagenic activity with either TA98 and TA100 strains dose-dependently with or without addition of S9 (Fig.3). It is interesting to note that the $m$-nitro analog (5m) is selectively active to TA100. In contrast, the $p$-nitro derivative (5p) showed potent mutagenicity to TA98 and at higher concentrations, cell killing occurred with TA100. On the other hand, the $o$-nitro derivative (50) showed no activity to either

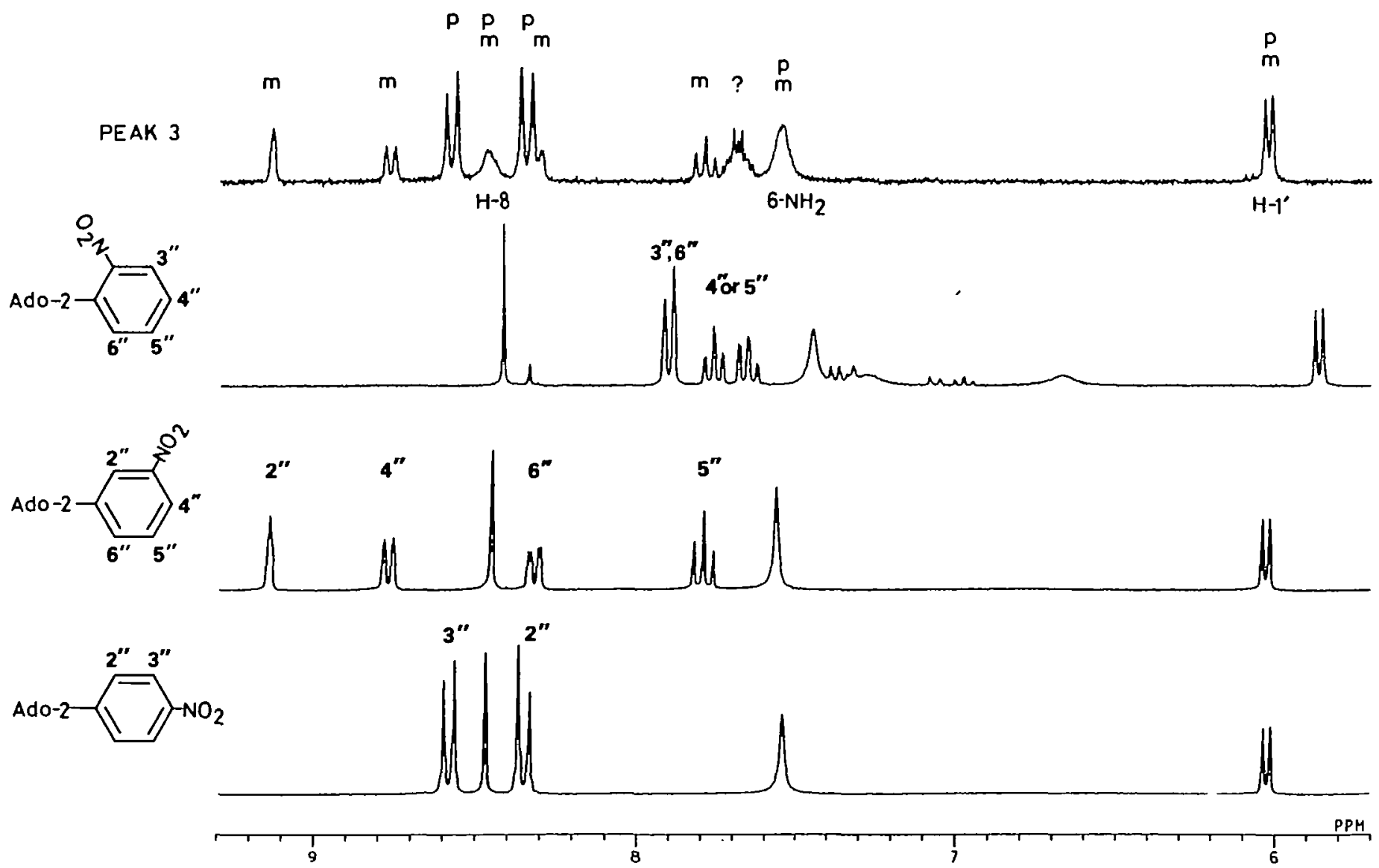

Figure 2. $270 \mathrm{MHz}{ }^{1} \mathrm{H}-\mathrm{NMR}$ spectrum of peak $3,50,5 \mathrm{~m}$, and $5 \mathrm{p}$ in DMSO-d 6 . 
strains. From these results, it is clear that during the diazotization of 1 in benzene with isopentyl nitrite, the intermediate(s) was nitrated to produce 2 -( $m$ - and $p$-nitrophenyl)-adenosines as minor components, which caused the mutagenicity from crude 3 .

Some aromatic nitro compounds are mutagenic. For example, 4-nitroquinoline $\mathrm{N}$-oxide and dinitropyrenes have been shown to have potent mutagenicity and carcinogenicity. Nitropyrene and dinitropyrenes especially are known to be common mutagenic environmental contaminants. Thus, it is interesting to study whether the mutagenicity of $\mathbf{5 m}$ and $\mathbf{5 p}$ arises from the nucleosidic character or whether they are behaving just as aromatic nitro compounds.

To clarify further the structural requirements for the mutagenicity, several nucleoside and base analogs were prepared. 2-(p-Nitrophenyl)-adenosine (5p) was deaminated with sodium nitrite in aqueous acetic acid at room temperature for 4 days to give the inosine derivative (8) in $71 \%$ yield. The nitro group in compound $5 p$ was reduced by catalytic hydrogenation with $10 \%$ palladium on carbon, and the anilino adenosine (6) was obtained in $50 \%$ yield. Nucleosides $5 \mathrm{~m}, 5 \mathrm{p}$, and 8 were treated with $2 \mathrm{~N}$ hydrochloric acid to afford the corresponding 2-( $m$ - and $p$ nitrophenyl)-adenines (7m and $7 \mathbf{p}$ ) and 2-(nitrophenyl)hypoxanthine (9) (Scheme 3). As sugar analogs of $5 \mathrm{~m}$ and 5p, 2 -( $m$ - and $p$-nitrophenyl)-2'-deoxyadenosines $(15 \mathrm{~m}$ and $15 \mathrm{p})$ were next synthesized. 5-Amino-4-cyanoimidazole riboside (10) was treated with 1,3-dichloro-1,1,3,3-tetraisopropyldisiloxane (TIPDSCl ${ }_{2}$ ) in $N, N$-dimethylformamide (DMF) to give the corresponding $3^{\prime}, 5^{\prime}, O$-tetraisopropyldisiloxanyl (TIPDS) derivative (11) in $74 \%$ yield after purification over a silica gel column ${ }^{13}$. Compound 11 was then treated with $N, N$ thiocarbonyldiimidazole in DMF to afford the 2'-thiocarbonyl derivative (12) in a crystalline form (72\% yield). 12 was subjected to radical-deoxygenation with tributyltin hydride ${ }^{14}$ in toluene, giving the desired 2'-deoxynucleoside (13) exclusively. Compound 13 was then cyclized with $m$ - and $p$-nitrobenzonitriles in ethanolic ammonia to afford the $2-(m$ - and $p$-nitrophenyl)deoxyadenosine derivatives (14m and 14p) in $48 \%$ and $84 \%$ yield, respectively. The nucleosides were deblocked with tetrabutylammonium fluoride in tetrahydrofuran to furnish 2-( $m$ and $p$-nitrophenyl)-2'-deoxyadenosines (15m and 15p), respectively, in good yields. In contrast, when the same radical deoxygenation was applied to the 2 '-thiocarbonyl-2-( $p$ nitrophenyl)-adenosine derivative, only a complex mixture was obtained (data not shown).

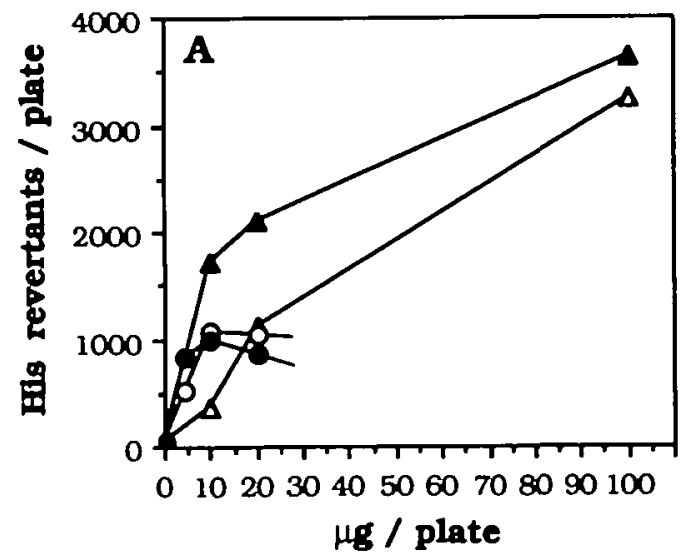

The mutagenicity of the nucleosides and bases toward $S$. typhimurium TA98 and TA 100 in the absence or presence of S9 is summarized in Table 1. Data for known mutagens, $\mathrm{N}^{4}$-aminocytidine, 4-nitroquinoline $\mathrm{N}$-oxide (4NQO) and benzo[a]pyrene (BP), are also shown for comparison. Among

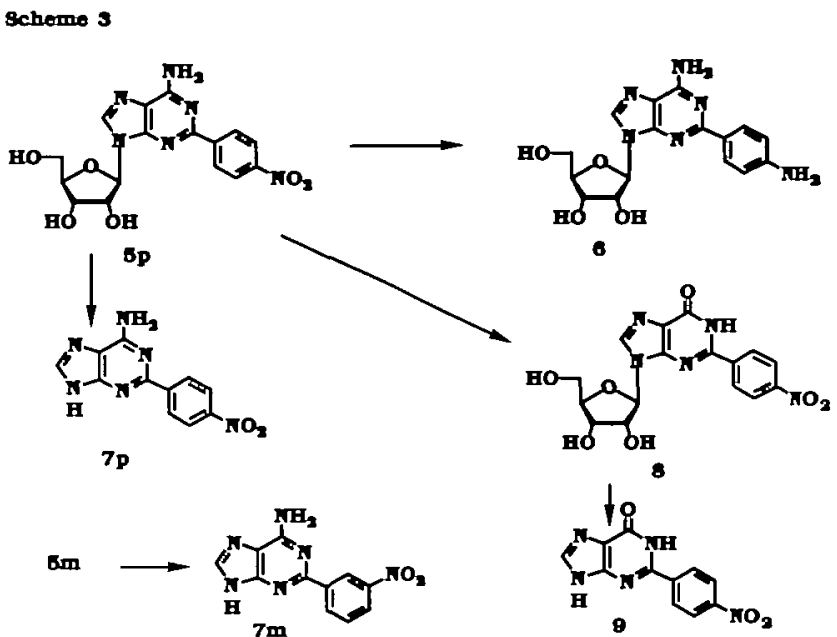

Behomo 4
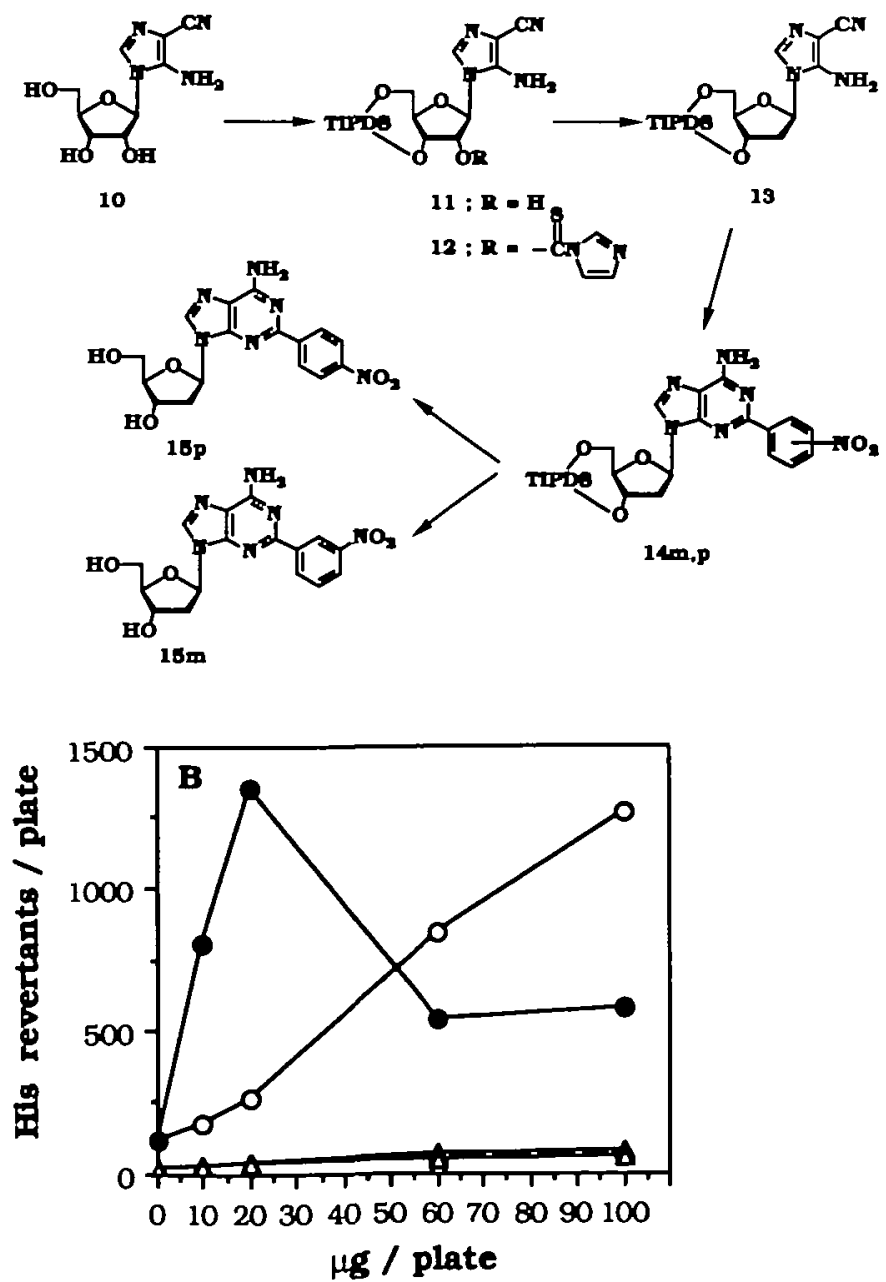

Figgure 3. Mutagenicity of $5 \mathrm{p}$ (A) and $5 \mathrm{~m}$ (B) on S. typhimurium TA98 and TA100. Circle symbols, TA100; triangle symbols, TA98. Solid symbols, - S9: open symbols, +\$9. 
Table 1. Mutagenicity of 2-(nitrophenyl)-adenınes on $S$.tpphımurium ${ }^{a}$

\begin{tabular}{|c|c|c|c|c|}
\hline \multirow{2}{*}{$\begin{array}{l}\text { Bacteria } \\
\text { Compds }\end{array}$} & \multicolumn{2}{|c|}{ TA98 } & \multicolumn{2}{|c|}{ TA100 } \\
\hline & $+\mathbf{S 9}$ & $-S 9$ & $+\$ 9$ & -59 \\
\hline $5 p$ & 820 & 1700 & 940 & 870 \\
\hline $5 \mathrm{~m}$ & 4 & 7 & 51 & 680 \\
\hline 50 & 0 & 0 & 0 & 0 \\
\hline 6 & 79 & 24 & 0 & 8 \\
\hline 8 & 193 & 546 & 224 & 575 \\
\hline $7 p$ & 1000 & 30000 & 1100 & 40000 \\
\hline $7 m$ & 0 & 0 & 100 & 900 \\
\hline 9 & 40 & 1000 & 0 & 1300 \\
\hline $15 p$ & 67000 & 117000 & 16000 & 42000 \\
\hline $15 \mathrm{~m}$ & 58 & 200 & 180 & 200 \\
\hline $\mathbf{N}^{4}$-aminocytidine & 0 & 0 & 3400 & 1300 \\
\hline $4 N Q O$ & 0 & 18000 & 0 & 80000 \\
\hline $\mathbf{B P}$ & 1200 & 0 & 2400 & 0 \\
\hline
\end{tabular}

Net number of revertants/10 $\mu g$ of compound per plate

the $p$-, $m$-, or $o$-nitrophenyladenosine derivatives $(5 \mathrm{p}, \mathrm{m}, \mathbf{0})$, the $p$-nitrophenyl derivative (5p) is the most potent. The $m$ nitrophenyl derivative $(5 \mathrm{~m})$ is active only to TA100 without metabolic activation. On the other hand, $o$-nitrophenyl derivative (50) is inactive with either strains. The $o$-nitrophenyl ring cannot be coplanar with the adenine ring because of steric repulsion between the $o$-nitro group and the pyrimidine moiety of adenine ring. This is probably one reason why $\mathbf{5 0}$ did not show mutagenic activity. The anilino derivative (6) is almost inactive. The inosine analog 8 shows weaker activity than the corresponding adenosine analog 5p. 2-(p-Nitrophenyl)-adenine (7p) is found to be much more potent than the nucleoside, whereas the 2-(m-nitrophenyl)adenine $(7 \mathrm{~m})$ is less mutagenic but selective toward TA100. Again, the hypoxanthine derivative (9) is, as expected, less potent than the adenine derivative. Surprisingly, 2-(pnitrophenyl)-2'-deoxyadenosine (15p) is the most potent among 2 -nitrophenyladenines in the reversion of TA98 and TA100, and the activity toward TA98 is one order of magnitude greater than that of 4-nitroquinoline $\mathrm{N}$-oxide. Consistent with the weak mutagenicity of $5 \mathrm{~m}, \mathbf{1 5 m}$ shows only weak activity. These data indicate that the $p$-nitrophenyl analog is the most potent and the adenine analogs are always more active than the hypoxanthine analogs. The order of mutagenicity is the 2'-deoxynucleosides, the bases and the ribonucleosides.

It is important to elucidate the role of the nitro group for the mutagenicity. When 5p was tested towards nitroreductase deficient strains (TA98/1,8-DNP and TA98NR), none of the strains (without addition of S9) showed significant number of his $^{+}$revertants ( 82 and 54 revertants at the concentration of 20 $\mu \mathrm{g} /$ plates, respectively) while TA98 gave 2200 revertants under the same conditions. Compound $7 p$ ( $1 \mu \mathrm{g} /$ plate) showed a low activity to TA 100/1,8-DNP (570 revertants) and TA100NR (160 revertants) while TA 100 gave 3230 revertants. Although 15p did not show any activity toward TA100/1,8 DNP and TA100NR at $0.5 \mu \mathrm{g} /$ plate. TA 100 formed 1550 revertants. Thus, it is obvious that the nitro group is essential for the mutagenicity.

The mutagenic activity of 15p to FM3A cells was also investigated by measuring mutations to ouabain resistance. As shown in Table 2, 15p exhibited mutagenicity with a potency close to that of $\mathrm{N}^{4}$-aminocytidine ${ }^{15}$. Since $\mathrm{EC}_{50}$ of $15 \mathrm{p}$ for FM3A cells was $3.2 \times 10^{-5} \mathrm{M}$, this reagent showed no cytotoxicity at the concentrations tested for the mutagenicity.

From these studies, one can speculate that $2-(p-$ nitrophenyl)adenine $(7 p)$ and the $2^{\prime}$-deoxy analog $(15 p)$, like other nitro aromatic compounds, would be reduced to the hydroxylamino
Table 2. Mutation assay in FM3A cells

\begin{tabular}{|c|c|c|c|}
\hline Concentration [M] & $\begin{array}{l}\text { No. of ouabain } \\
\text { resistant mutants } \\
\text { scored/total No. } \\
\text { of original cells }\end{array}$ & $\begin{array}{l}\text { Mutation frequency } \\
\left(\text { ouas }^{5} \Rightarrow \text { ous }^{r}\right)^{a}\end{array}$ & $\begin{array}{l}\text { Colony-forming } \\
\text { ability }(\%) \\
\pm \text { S.D }(n=15)\end{array}$ \\
\hline \multicolumn{4}{|c|}{ 2-(p-Nitrophenyl)-2'-deoxyadenosine (15p) } \\
\hline Control:0 & $0 / 1.5 \times 10^{7}$ & 0 & $84.9 \pm 9.8$ \\
\hline $5.4 \times 10^{-6}$ & $31 / 1.4 \times 10^{7}$ & $2.5 \times 10^{-6}$ & $90.3 \pm 8.8$ \\
\hline $10 \times 10^{-5}$ & $68 / 1.5 \times 10^{7}$ & $5.3 \times 10^{-6}$ & $85.1 \pm 12.4$ \\
\hline \multicolumn{4}{|l|}{$N^{4}$-Aminocytidıne ${ }^{b}$} \\
\hline $3.0 \times 10^{-5}$ & $87 / 9.5 \times 10^{6}$ & $1.1 \times 10^{-5}$ & 86 \\
\hline
\end{tabular}

'(Number of mutants) / (number of original cells $\times$ colony-forming ability)

bData taken from ref. 15 .

derivatives by the action of nitroreductase, and that these activated bases would react with DNA to form adducts. Also, the hydroxylamino derivatives may be further activated by acylation and/or sulfation for the reaction with DNA. On the other hand, in the case of the $2^{\prime}$-deoxy compound (15p), it might be phosphorylated and incorporated into DNA after or before activation of the nitro group. The detailed mechanism of the mutagenic action of these compounds is a subject of further studies.

\section{EXPERIMENTAL}

Melting points were determined on a Yanagimoto MP-3 micromelting point apparatus and are uncorrected. The ' $\mathbf{H}$ NMR spectra were recorded on a JEOL FT100FT or FX-270FT spectrometer with tetramethylsilane as an internal standard. Chemical shifts are reported in parts per million $(\delta)$, and signals are expressed as $s$ (singlet), $d$ (doublet), $t$ (triplet), $q$ (quartet), $m$ (multiplet), or br (broad). All exchangeable protons were detected by addition of $\mathrm{D}_{2} \mathrm{O}$. UV absorption spectra were recorded with a Shimadzu UV-240 spectrophotometer. Electron impact mass spectra (Mass) were measured on a JEOL D-300 spectrometer. TLC was performed on Merck Kieselgel F254 precoated plates. Silica gel used for column chromatography was YMC gel 60A (70-230 mesh). HPLC analyses were performed on a JASCO TRI ROTAR-V system using Shodex ODS pak F-411 $(4.6 \times 150 \mathrm{~mm})$ with $40 \%$ aqueous methanol as an eluting solvent at a flow rate of $1 \mathrm{ml} / \mathrm{min}$.

2-(p-Nitrophenyl)-adenosine (5p). A mixture of $2^{\prime}, 3^{\prime}, 5^{\prime}$-tri$O$-acetyl-5-amino-4-cyanoimidazole riboside $(4 ; 2.0 \mathrm{~g}, 5.5 \mathrm{mmol})$ and $p$-nitrobenzonitrile $(2.0 \mathrm{~g}, 13.5 \mathrm{mmol})$ in methanolic ammonia (saturated at $0^{\circ} \mathrm{C}, 30 \mathrm{ml}$ ) was heated at $170^{\circ} \mathrm{C}$ in a sealed steel tube. After $6 \mathrm{~h}$, the tube was cooled to room temperature, opened, and the resulting precipitates were collected by filtration ( $5 \mathrm{p} ; 1.5 \mathrm{~g}, 71 \%)$. Analytical sample was obtained by recrystallization from aqueous ethanol, $\mathrm{mp} 252-253^{\circ} \mathrm{C}$. Mass $m / z: 388\left(\mathrm{M}^{+}\right)$. ${ }^{1} \mathrm{H}-\mathrm{NMR}$ (DMSO-d $\left.{ }_{6}\right): \delta 3.62(\mathrm{~m}, 2 \mathrm{H}$, $\left.5^{\prime}, 5^{\prime \prime}-\mathrm{H}\right), 3.97\left(\mathrm{~m}, 1 \mathrm{H}, 4^{\prime}-\mathrm{H}\right), 4.21\left(\mathrm{~m}, 1 \mathrm{H}, 3^{\prime}-\mathrm{H}\right), 4.68(\mathrm{~m}$, $\left.1 \mathrm{H}, 2^{\prime}-\mathrm{H}\right), 5.03\left(\mathrm{t}, 1 \mathrm{H}, 5^{\prime}-\mathrm{OH}\right), 5.25\left(\mathrm{~d}, 1 \mathrm{H}, 2^{\prime}-\right.$ or $\left.3^{\prime}-\mathrm{OH}\right)$, $5.50\left(\mathrm{~d}, 1 \mathrm{H}, 3^{\prime}-\right.$ or $\left.2^{\prime}-\mathrm{OH}\right), 6.02\left(\mathrm{~d}, 1 \mathrm{H}, 1^{\prime}-\mathrm{H}, \mathrm{J}_{1^{\prime} 2^{\prime}}=5.9 \mathrm{~Hz}\right)$, 7.54 (brs, $\left.2 \mathrm{H}, 6-\mathrm{NH}_{2}\right), 8.35\left(\mathrm{~d}, 2 \mathrm{H}, 2^{\prime \prime}\right.$ and $6^{\prime \prime}, \mathrm{J}_{2^{\prime \prime}, 3^{\prime \prime}}=\mathrm{J}_{5^{\prime \prime}, 6^{\prime \prime}}$ $=8.8 \mathrm{~Hz}), 8.47(\mathrm{~s}, 1 \mathrm{H}, 8-\mathrm{H}), 8.58\left(\mathrm{~d}, 2 \mathrm{H}, 3^{\prime \prime}\right.$ and $\left.5^{\prime \prime} \mathrm{H}\right)$. Anal. Calcd for $\mathrm{C}_{16} \mathrm{H}_{16} \mathrm{~N}_{6} \mathrm{O}_{6}: \mathrm{C}, 49.49 ; \mathrm{H}, 4.15 ; \mathrm{N}, 21.64$. Found: C, 49.34; H, 4.09; N, 21.58.

2-(m-Nitrophenyl)-adenosine (5m). A mixture of compound $4(1.0 \mathrm{~g}, 2.7 \mathrm{mmol})$ and $m$-nitrobenzonitrile $(1.0 \mathrm{~g}, 6.8 \mathrm{mmol})$ in methanolic ammonia $(30 \mathrm{ml})$ in a sealed steal tube was heated at $170^{\circ} \mathrm{C}$ for $8 \mathrm{~h}$. The resulting solution was evaporated to dryness 
Nucleic Acids Research, Vol. 18, No. 71837

and the residue was dissolved in methanol. Silica gel was added to the methanol solution, and the mixture was evaporated to dryness. The residue was placed on a silica gel column, which was eluted with chloroform containing $5 \%$ ethanol then eluted with chloroform containing $10 \%$ ethanol. From the latter fractions, the desired nucleoside was obtained and the residue was crystallized from aqueous ethanol to give $5 \mathrm{~m}(541 \mathrm{mg}, 51 \%)$; $\mathrm{mp} 235-236^{\circ} \mathrm{C}$ (sintering from $223^{\circ} \mathrm{C}$ ). Mass $\mathrm{m} / 2: 388\left(\mathrm{M}^{+}\right)$. 'H-NMR (DMSO-d $)$ : $\delta 3.60\left(\mathrm{~m}, 2 \mathrm{H}, \mathrm{S}^{\prime}, 5^{\prime \prime}-\mathrm{H}\right), 3.98(\mathrm{~m}, 1 \mathrm{H}$, $\left.4^{\prime}-\mathrm{H}\right), 4.21\left(\mathrm{~m}, 1 \mathrm{H}, 3^{\prime}-\mathrm{H}\right), 4.68\left(\mathrm{~m}, 1 \mathrm{H}, 2^{\prime}-\mathrm{H}\right), 5.03(\mathrm{t}, 1 \mathrm{H}$, $\left.5^{\prime}-\mathrm{OH}\right), 5.25\left(\mathrm{~d}, 1 \mathrm{H}, 2^{\prime}-\right.$ or $\left.3^{\prime}-\mathrm{OH}\right), 5.50\left(\mathrm{~d}, 1 \mathrm{H}, 3^{\prime}-\right.$ or $\left.2^{\prime}-\mathrm{OH}\right)$, $6.03\left(\mathrm{~d}, 1 \mathrm{H}, 1^{\prime}-\mathrm{H}, \mathrm{J}_{\mathrm{I}^{\prime}, 2^{\prime}}=6.3 \mathrm{~Hz}\right), 7.57$ (brs, $2 \mathrm{H}, 6-\mathrm{NH}_{2}$ ), $7.79\left(\mathrm{t}, 1 \mathrm{H}, 5^{\prime \prime}-\mathrm{H}, \mathrm{J}_{4^{\prime \prime}} \mathrm{s}^{\prime \prime}=8.1 \mathrm{~Hz}\right), 8.32\left(\mathrm{dd}, 1 \mathrm{H}, 6^{\prime \prime}-\mathrm{H}\right.$, $\left.\mathrm{J}_{4^{\prime \prime}, 6^{\prime \prime}}=1.1 \mathrm{~Hz}, \mathrm{~J}_{5^{\prime \prime}, 6^{\prime \prime}}=8.1 \mathrm{~Hz}\right), 8.45(\mathrm{~s}, 1 \mathrm{H}, 8-\mathrm{H}), 8.77(\mathrm{dd}$, $\left.1 \mathrm{H}, 4^{\prime \prime}-\mathrm{H}, \mathrm{J}_{2^{\prime \prime} 4^{\prime \prime}}=1.5 \mathrm{~Hz}, \mathrm{~J}_{4^{\prime \prime}} 5^{\prime \prime}=8.1 \mathrm{~Hz}\right), 9.14(\mathrm{t}, 1 \mathrm{H}$, $2 "$ '-H). Anal. Calcd for $\mathrm{C}_{16} \mathrm{H}_{16} \mathrm{~N}_{6} \mathrm{O}_{6}: \mathrm{C}, 49.49 ; \mathrm{H}, 4.15 ; \mathrm{N}$, 21.64. Found: $\mathrm{C}, 49.28 ; \mathrm{H}, 4.30 ; \mathrm{N}, 21.41$.

2-(o-Nitrophenyl)-adenosine (50). A mixture of compound 4 $(1.0 \mathrm{~g}, 2.7 \mathrm{mmol})$ and $o$-nitrobenzonitrile $(1.0 \mathrm{~g}, 6.8 \mathrm{mmol})$ in methanolic ammonia $(30 \mathrm{ml})$ in a sealed steel tube was heated at $170^{\circ} \mathrm{C}$ for $8 \mathrm{H}$. The resulting solution was vaporated to dryness and the residue was dissolved in methanol. Silica gel was added to the methanol solution, and the mixture was evaporated to dryness. The residue was placed on a silica gel column, which was eluted with chloroform containing $5 \%$ ehtanol then eluted with chloroform containing $10 \%$ ethanol. From the latter fractions, the desired nucleoside (50) was obtained as a foam (214 $\mathrm{mg}, 20 \%$ ). Mass $\mathrm{m} / z: 388\left(\mathrm{M}^{+}\right)$. ' $\mathrm{H}-\mathrm{NMR}$ (DMSO-d $\left.\mathrm{d}_{6}\right): \delta 3.60$ $\left(\mathrm{m}, 2 \mathrm{H}, 5^{\prime}, 5^{\prime \prime}-\mathrm{H}\right), 3.93\left(\mathrm{~m}, 1 \mathrm{H}, 4^{\prime}-\mathrm{H}\right), 4.13\left(\mathrm{~m}, 1 \mathrm{H}, 3^{\prime}-\mathrm{H}\right)$, $4.60\left(\mathrm{~m}, 1 \mathrm{H}, 2^{\prime}-\mathrm{H}\right), 5.08\left(\mathrm{t}, 1 \mathrm{H}, 5^{\prime}-\mathrm{OH}\right), 5.17\left(\mathrm{~d}, 1 \mathrm{H}, 2^{\prime}-\right.$ or $\left.3^{\prime}-\mathrm{OH}\right), 5.42\left(\mathrm{~d}, 1 \mathrm{H}, 3^{\prime}-\right.$ or $\left.2^{\prime}-\mathrm{OH}\right), 5.86\left(\mathrm{~d}, 1 \mathrm{H}, 1^{\prime}-\mathrm{H}^{\prime}, \mathrm{J}^{\prime}, 2^{\prime}\right.$ $=5.9 \mathrm{~Hz}), 7.45\left(\mathrm{brs}, 2 \mathrm{H}, 6-\mathrm{NH}_{2}\right), 7.67\left(\mathrm{dt}, 1 \mathrm{H}, 4^{\prime \prime}-\right.$ or $5^{\prime \prime}-\mathrm{H}$, $\left.\mathrm{J}_{3^{\prime \prime}, 4^{\prime \prime}}=\mathrm{J}_{4^{\prime \prime}, 5^{\prime \prime}}=\mathrm{J}_{5^{\prime \prime}, 6^{\prime \prime}}=7.7 \mathrm{~Hz}, \mathrm{~J}_{3^{\prime \prime}, 5^{\prime \prime}}=\mathrm{J}_{4^{\prime \prime}, 6^{\prime \prime}}=1.5 \mathrm{~Hz}\right)$, $7.76\left(\mathrm{dt}, 1 \mathrm{H}, 5^{\prime \prime}\right.$ - or $\left.4^{\prime \prime}-\mathrm{H}\right), 7.90\left(\mathrm{~d}, 2 \mathrm{H}, 3^{\prime \prime}-\right.$ and $\left.6^{\prime \prime}-\mathrm{H}\right), 8.42$ $(\mathrm{s}, 1 \mathrm{H}, 8-\mathrm{H})$.

2-(p-Aminophenyl)-adenosine (6). 10\% Palladium on carbon $(30 \mathrm{mg})$ was added to a solution of $5 p(250 \mathrm{mg})$ in a mixture of ethanol $(10 \mathrm{ml})$ and $50 \%$ aqueous acetic acid $(20 \mathrm{ml})$. The mixture was stirred at room temperature under $\mathrm{H}_{2}$ atmosphere, until a theoretical amount of $\mathrm{H}_{2}$ was absorbed. The reaction mixture was passed through a celite pad and the eluent was evaporated to dryness. The residue was crystallized from water to give $6(115 \mathrm{mg}, 50 \%) ; \mathrm{mp} 229-231^{\circ} \mathrm{C}$. Mass $\mathrm{m} / \mathrm{z}$ : 358 $\left(\mathrm{M}^{+}\right)$. ' $\mathrm{H}-\mathrm{NMR}\left(\mathrm{DMSO}-\mathrm{d}_{6}+\mathrm{D}_{2} \mathrm{O}\right): \delta 3.55\left(\mathrm{dd}, 1 \mathrm{H}, 5^{\prime}-\mathrm{H}\right.$, $\left.\mathrm{J}_{4^{\prime}, 5^{\prime}}=4.0 \mathrm{~Hz}, \mathrm{~J}_{5^{\prime}, 5^{\prime \prime}}=11.7 \mathrm{~Hz}\right), 3.67\left(\mathrm{dd}, 1 \mathrm{H}, 5^{\prime \prime}-\mathrm{H}, \mathrm{J}_{4^{\prime}, 5^{\prime \prime}}\right.$ $=4.0 \mathrm{~Hz}), 3.93\left(\mathrm{dd}, 1 \mathrm{H}, 4^{\prime}-\mathrm{H}\right), 4.20\left(\mathrm{dd}, 1 \mathrm{H}, 3^{\prime}-\mathrm{H}\right), 4.70(\mathrm{dd}$, $\left.1 \mathrm{H}, 2^{\prime}-\mathrm{H}\right), 5.94\left(\mathrm{~d}, 1 \mathrm{H}, 1^{\prime}-\mathrm{H}, \mathrm{J}_{1^{\prime}, 2^{\prime}}=6.2 \mathrm{~Hz}\right), 6.60(\mathrm{~d}, 2 \mathrm{H}$, phenyl, $\mathrm{J}=8.4 \mathrm{~Hz}), 8.04(\mathrm{~d}, 2 \mathrm{H}$, phenyl, $\mathrm{J}=8.4 \mathrm{~Hz}), 8.28$ (s, 1H, 8-H). Anal. Calcd for $\mathrm{C}_{16} \mathrm{H}_{18} \mathrm{~N}_{6} \mathrm{O}_{4}: \mathrm{C}, 53.63 ; \mathrm{H}, 5.06$; $\mathrm{N}, 23.45$. Found: $\mathrm{C}, 53.73 ; \mathrm{H}, 5.16 ; \mathrm{N}, 23.16$.

2-(p-Nitrophenyl)-inosine (8). Sodium nitrite $(280 \mathrm{mg}, 4.1$ mmol) was added to a suspension of $5 p(250 \mathrm{mg}, 0.64 \mathrm{mmol})$ in $50 \%$ aqueous acetic acid at $0^{\circ} \mathrm{C}$. The reaction mixture was stirred for 4 days at room temperature under a tight sealing. The resulting precipitate was collected by filtration and the solid was crystallized from $50 \%$ aqueous ethanol to afford $8(142 \mathrm{mg}$, $71 \%) ; \mathrm{mp} 180-183^{\circ} \mathrm{C}$. Mass $\mathrm{m} / \mathrm{z}: 257(\mathrm{~B}+\mathrm{H})^{+}$. 'H-NMR $\left(\mathrm{DMSO}^{-\mathrm{d}_{6}}+\mathrm{D}_{2} \mathrm{O}\right): \delta 3.56\left(\mathrm{dd}, 1 \mathrm{H}, 5^{\prime}-\mathrm{H}, \mathrm{J}_{4^{\prime} 5^{\prime}}=3.8 \mathrm{~Hz}\right.$, $\left.\mathrm{J}_{5^{\prime}, 5^{\prime \prime}}=11.5 \mathrm{~Hz}\right), 3.66\left(\mathrm{dd}, 1 \mathrm{H}, 5^{\prime \prime}-\mathrm{H}, \mathrm{J}_{4^{\prime}} \mathrm{s}^{\prime \prime}=3.8 \mathrm{~Hz}\right), 3.96$ (dd, $\left.1 \mathrm{H}, 4^{\prime}-\mathrm{H}\right), 4.17$ (dd, $\left.1 \mathrm{H}, 3^{\prime}-\mathrm{H}\right), 4.57$ (dd, $\left.1 \mathrm{H}, 2^{\prime}-\mathrm{H}\right), 5.98$ $\left(\mathrm{d}, 1 \mathrm{H}, 1^{\prime}-\mathrm{H}, \mathrm{J}_{1^{\prime}, 2^{\prime}}=6.0 \mathrm{~Hz}\right), 8.37(\mathrm{~m}, 4 \mathrm{H}$, phenyl), $8.42(\mathrm{~s}$, $1 \mathrm{H}, 8-\mathrm{H})$. Anal. Calcd for $\mathrm{C}_{16} \mathrm{H}_{15} \mathrm{~N}_{5} \mathrm{O}_{7} \cdot 0.5 \mathrm{H}_{2} \mathrm{O}: \mathrm{C}, 48.24 ; \mathrm{H}$, $4.05 ; \mathrm{N}, 17.58$. Found: $\mathrm{C}, 48.54 ; \mathrm{H}, 3.90 ; \mathrm{N}, 17.45$.
2-(p-Nitrophenyl)-adenine (7p). A suspension of $5 p(250 \mathrm{mg})$ in $2 \mathrm{~N} \mathrm{HCl}(20 \mathrm{ml})$ was heated at $60^{\circ} \mathrm{C}$ for 1 day with stirring. The resulting erystals were collected by filtration $(7 \mathrm{p} ; 154 \mathrm{mg}$, $87 \%$ as hydrate); $\mathrm{mp}>300^{\circ} \mathrm{C}$. Mass $\mathrm{m} / \mathrm{z}: 256\left(\mathrm{M}^{+}\right)$. Anal. Calcd for $\mathrm{C}_{11} \mathrm{H}_{8} \mathrm{~N}_{6} \mathrm{O}_{2} \cdot \mathrm{H}_{2} \mathrm{O}: \mathrm{C}, 48.18 ; \mathrm{H}, 3.68 ; \mathrm{N}, 30.64$. Found: C, 47.81; H, 3.36; N, 30.34.

2-(m-Nitrophenyl)-adenine $(7 \mathrm{~m})$. A suspension of $5 \mathrm{~m}(120 \mathrm{mg})$ in $2 \mathrm{~N} \mathrm{HCl}(10 \mathrm{ml})$ was heated at $60^{\circ} \mathrm{C}$ for 1 day with stirring. Ethanol ( $15 \mathrm{ml})$ was added to the mixture, which was heated until the insoluble materials were dissolved. The resulting solution was filtered and from the filtrate crystalline materials were obtained $(7 \mathrm{~m} ; 75 \mathrm{mg}, 95 \%) ; \mathrm{mp}>300^{\circ} \mathrm{C}$. Mass $\mathrm{m} / \mathrm{z}: 256$ $\left(\mathrm{M}^{+}\right)$. Anal. Calcd for $\mathrm{C}_{11} \mathrm{H}_{8} \mathrm{~N}_{6} \mathrm{O}_{2}: \mathrm{C}, 51.56 ; \mathrm{H}, 3.15 ; \mathrm{N}$, 32.80. Found: C, $51.53 ; \mathrm{H}, 3.08 ; \mathrm{N}, 32.83$.

2-(p-Nitrophenyl)-hypoxanthine (9). A suspension of $8(68 \mathrm{mg})$ in $2 \mathrm{~N} \mathrm{HCl}(10 \mathrm{ml})$ was heated at $60^{\circ} \mathrm{C}$ for 1 day with stirring. The resulting crystals were collected by filtration to give 9 (36 $\mathrm{mg}$, as a hemihydrate); $\mathrm{mp}>300^{\circ} \mathrm{C}$. Mass $\mathrm{m} / \mathrm{z}: 257\left(\mathrm{M}^{+}\right)$. Anal. Calcd for $\mathrm{C}_{11} \mathrm{H}_{7} \mathrm{~N}_{5} \mathrm{O}_{3} \cdot 0.5 \mathrm{H}_{2} \mathrm{O}: \mathrm{C}, 49.62 ; \mathrm{H}, 3.03 ; \mathrm{N}$, 26.31. Found: $\mathrm{C}, 49.24 ; \mathrm{H}, 3.07 ; \mathrm{N}, 26.01$.

5-Amino-1-(3',5'-O-TIPDS- $\beta$-D-ribofuranosyl)-imidazole-4carbonitrile (11). $\operatorname{TIPDSCl}_{2}(6.92 \mathrm{~g}, 1.1$ equiv.) was added to a solution of $10(4.8 \mathrm{~g}, 20 \mathrm{mmol})$ in dry pyridine $(50 \mathrm{ml})$ at $0^{\circ} \mathrm{C}$. The mixture was stirred for $4.5 \mathrm{~h}$ at room temperature. Ice water (ca. $5 \mathrm{ml}$ ) was added to the mixture and the mixture was concentrated by evaporation. This residue was coevaporated several times with aqueous ethanol. The residue was dissolved in ethyl acetate (ca. $100 \mathrm{ml}$ ) and the mixture was washed with water $(20 \mathrm{ml} \times 3)$. The organic layer was dried $\left(\mathrm{Na}_{2} \mathrm{SO}_{4}\right)$ and evaporated to dryness to leave a powder, which was crystallized from hexane to afford $11(7.25 \mathrm{~g}, 75 \%)$; $\mathrm{mp}$ $163-164^{\circ} \mathrm{C}$. Mass $m / z: 482\left(\mathrm{M}^{+}\right)$. ${ }^{1} \mathrm{H}-\mathrm{NMR}\left(\mathrm{CDCl}_{3}+\mathrm{D}_{2} \mathrm{O}\right)$ : $\delta 1.09\left(\mathrm{~m}, 28 \mathrm{H}\right.$, isopropyl), $4.06\left(\mathrm{~m}, 4 \mathrm{H}, 3^{\prime}, 4^{\prime}, 5^{\prime}, 5^{\prime \prime}-\mathrm{H}\right), 5.55$ (d, $\left.1 \mathrm{H}, 11^{\prime}-\mathrm{H}\right), 7.16(\mathrm{~s}, 1 \mathrm{H}, 2-\mathrm{H})$. Anal. Calcd for $\mathrm{C}_{21} \mathrm{H}_{38} \mathrm{~N}_{4} \mathrm{O}_{5} \mathrm{Si}_{2}: \mathrm{C}, 52.25 ; \mathrm{H}, 7.93 ; \mathrm{N}, 11.61$. Found: $\mathrm{C}, 52.20$; $\mathrm{H}, 7.94 ; \mathrm{N}, 11.54$.

5-Amino-1-(3',5'-O-TPIDS-2'-O-thiocarbonylimidazoyl- $\beta$ - $D$ ribofuranosyl)imidazole-4-carbonitrile (12). A solution of compound 11 (1.45 g, $3 \mathrm{mmol})$ and $N, N^{\prime}$-thiocarbonyldiimidazole ( $90 \%$ pure; $1.19 \mathrm{~g}, 2$ equiv.) in dry DMF $(15 \mathrm{ml})$ for $22 \mathrm{~h}$ at room temperature. The mixture was diluted with ethyl acetate $(100 \mathrm{ml})$ and was washed with water $(20 \mathrm{ml} \times 4)$. The separated organic phase was dried $\left(\mathrm{Na}_{2} \mathrm{SO}_{4}\right)$ and evaporated to dryness. The residue was crystallized from ethanol to give $12(1.29 \mathrm{~g}$, 72\%); mp $219-220^{\circ} \mathrm{C}$. Mass $\mathrm{m} / z: 592\left(\mathrm{M}^{+}\right)$. ' $\mathrm{H}-\mathrm{NMR}$ $\left(\mathrm{CDCl}_{3}\right): \delta 1.11(\mathrm{~m}, 28 \mathrm{H}$, isopropyl), $4.13(\mathrm{~m}, 3 \mathrm{H}$, $\left.4^{\prime}, 5^{\prime}, 5^{\prime \prime}-\mathrm{H}\right), 4.49$ (brs, 2H, 5- $\mathrm{NH}_{2}$ ), 4.98 (dd, 1H, 3'- $\left.3^{\prime}\right), 5.82$ $\left(\mathrm{m}, 2 \mathrm{H}, \mathrm{I}^{\prime}, 2^{\prime}-\mathrm{H}\right), 7.30(\mathrm{~s}, 1 \mathrm{H}, 2-\mathrm{H}), 7.10,7.65,8.35$ (each $\mathrm{m}$, each 1H, imidazole protons). Anal. Calcd for $\mathrm{C}_{25} \mathrm{H}_{40} \mathrm{~N}_{6} \mathrm{O}_{5} \mathrm{SSi}_{2}$ : C, 50.65; H, 6.80; N, 14.17. Found: C, 50.37; H, 6.71; N, 14.25 .

5-Amino-1-(2'-deoxy-3',5'-O-TIPDS- $\beta$-D-ribofuranosyl)imidazole-4-carbonitrile $(13)$. Tributyltin hydride $(0.87 \mathrm{ml}, 1.5$ equiv.) was added to suspension of $12(1.28 \mathrm{~g}, 2.16 \mathrm{mmol})$ and azobisisobutylonitrile $(50 \mathrm{mg})$ in dry toluene $(20 \mathrm{ml})$. The mixture was heated under reflux for $\mathbf{4 0}$ min and evaporated to dryness. The residue was purified by a silica gel column which was eluted with chloroform containing $1 \%$ ethanol. From this fraction, the desired nucleoside (13) was obtained $(1.0 \mathrm{~g}, 99 \%$; crystallized from hexane); mp $95-96^{\circ} \mathrm{C}$. Mass $m / z: 466\left(\mathrm{M}^{+}\right)$. ${ }^{1} \mathrm{H}-\mathrm{NMR}$ $\left(\mathrm{CDCl}_{3}\right): \delta 1.06\left(\mathrm{~m}, 28 \mathrm{H}\right.$, isopropyl), $2.52\left(\mathrm{~m}, 2 \mathrm{H}, 2^{\prime}, 2^{\prime \prime}-\mathrm{H}\right)$, $3.82\left(\mathrm{~m}, 1 \mathrm{H}, 4^{\prime}-\mathrm{H}\right), 3.97\left(\mathrm{~m}, 2 \mathrm{H}, 5^{\prime}, 5^{\prime \prime}-\mathrm{H}\right), 4.40$ (brs, $2 \mathrm{H}$, $\left.5-\mathrm{NH}_{2}\right), 4.75\left(\mathrm{~m}, 1 \mathrm{H}, 3^{\prime}-\mathrm{H}\right), 5.82\left(\mathrm{dd}, 1 \mathrm{H}, 1^{\prime}-\mathrm{H}\right), 7.09(\mathrm{~s}, 1 \mathrm{H}$, 
2-H). Anal. Calcd for $\mathrm{C}_{21} \mathrm{H}_{38} \mathrm{~N}_{4} \mathrm{O}_{4} \mathrm{Si}_{2}: \mathrm{C}, 54.04 ; \mathrm{H}, 8.21 ; \mathrm{N}$, 12.00. Found: $\mathrm{C}, 54.15 ; \mathrm{H}, 8.31 ; \mathrm{N}, 11.86$.

2'-Deoxy-3',5'-O-TIPDS-2-(p-nitrophenyl)-adenosine (14p). A mixture of $13(760 \mathrm{mg}, 1.6 \mathrm{mmol})$ and $p$-nitrobenzonitrile $(1.4$ $\mathrm{g}, 9.5 \mathrm{mmol}$ ) in ethanolic ammonia (saturated at $0^{\circ} \mathrm{C}, 30 \mathrm{ml}$ ) was heated at $170^{\circ} \mathrm{C}$ for $14 \mathrm{~h}$ in a sealed tube. The mixture was evaporated to dryness and the residue was suspended in chloroform. The insoluble material was removed by filtration with a celite pad and the filtrate was evaporated. The residue was crystallized from ethanol to give $14 \mathrm{p}(845 \mathrm{mg}, 84 \%)$; $\mathrm{mp}$ $216-218^{\circ} \mathrm{C}$. Mass $m / z: 614\left(\mathrm{M}^{+}\right) .{ }^{1} \mathrm{H}-\mathrm{NMR}\left(\mathrm{DMSO}-\mathrm{d}_{6}\right): \delta$ $2.61\left(\mathrm{~m}, 1 \mathrm{H}, 2^{\prime}-\mathrm{H}\right), 3.10\left(\mathrm{~m}, 1 \mathrm{H}, 2^{\prime \prime}-\mathrm{H}\right), 3.87(\mathrm{~m}, 3 \mathrm{H}$, $\left.4^{\prime}, 5^{\prime}, 5^{\prime \prime}-\mathrm{H}\right), 4.95\left(\mathrm{dd}, 1 \mathrm{H}, 3^{\prime}-\mathrm{H}\right), 6.42\left(\mathrm{dd}, 1 \mathrm{H}, 1^{\prime}-\mathrm{H}, \mathrm{J}_{1^{\prime}, 2^{\prime}}=\right.$ $\left.2.9 \mathrm{~Hz}, \mathrm{~J}_{1^{\prime}, 2^{\prime \prime}}=8.1 \mathrm{~Hz}\right), 7.56\left(\mathrm{brs}, 2 \mathrm{H}, 6-\mathrm{NH}_{2}\right), 8.32(\mathrm{~d}, 2 \mathrm{H}$, $\left.3^{\prime \prime}, 5^{\prime \prime}-\mathrm{H}, \mathrm{J}_{2^{\prime \prime}, 3^{\prime \prime}}=\mathrm{J}_{5^{\prime \prime}, 6^{\prime \prime}}=8.8 \mathrm{~Hz}\right), 8.33(\mathrm{~s}, 1 \mathrm{H}, 8-\mathrm{H}), 8.54$ (d, 1H, 2",6"'-H). Anal. Calcd for $\mathrm{C}_{28} \mathrm{H}_{42} \mathrm{~N}_{6} \mathrm{O}_{6} \mathrm{Si}_{2}$ : C, 54.70; $\mathrm{H}, 6.89 ; \mathrm{N}, 13.67$. Found: C, 54.27; H, 7.01; N, 13.54 .

2-Deoxy-2-(p-nitrophenyl)-adenosine (15p). A tetrahydrofuran solution of tetrabutylammonium fluoride $(1 \mathrm{M}, 0.8 \mathrm{ml})$ was added to a solution of $14 \mathrm{p}(221 \mathrm{mg}, 0.36 \mathrm{mmol})$ in dry tetrahydrofuran $(10 \mathrm{ml})$. The mixture was stirred for $30 \mathrm{~min}$ at room temperature and then neutralized with acetic acid. The solution was evaporated to dryness and the residue was crystallized from ethanol to afford 15p (95 mg, 71\%); $\mathrm{mp}>300^{\circ} \mathrm{C}$. Mass $\mathrm{m} / \mathrm{z}: 372\left(\mathrm{M}^{+}\right)$. ' $\mathrm{H}-$ NMR(DMSO-d $\left.\mathrm{d}_{6}\right): \delta 2.31-2.38\left(\mathrm{~m}, 1 \mathrm{H}, 2^{\prime}-\mathrm{H}\right), 2.77-2.81(\mathrm{~m}$, $\left.1 \mathrm{H}, 2^{\prime \prime}-\mathrm{H}\right), 3.60\left(\mathrm{~m}, 2 \mathrm{H}, 5^{\prime}, 5^{\prime \prime}-\mathrm{H}\right), 3.90\left(\mathrm{~m}, 1 \mathrm{H}, 4^{\prime}-\mathrm{H}\right), 4.47$ $\left(\mathrm{m}, 1 \mathrm{H}, 3^{\prime}-\mathrm{H}\right), 4.94\left(\mathrm{t}, 1 \mathrm{H}, 5^{\prime}-\mathrm{OH}\right), 5.36\left(\mathrm{~d}, 1 \mathrm{H}, 3^{\prime}-\mathrm{OH}\right), 6.47$ $\left(\mathrm{t}, 1 \mathrm{H}, 1^{\prime}-\mathrm{H}, \mathrm{J}_{1^{\prime}, 2^{\prime}}=7.0 \mathrm{~Hz}\right), 7.52\left(\mathrm{brs}, 2 \mathrm{H}, 6-\mathrm{NH}_{2}\right), 8.35(\mathrm{~d}$, $\left.2 \mathrm{H}, 2^{\prime \prime}, 6^{\prime \prime}-\mathrm{H}, \mathrm{J}_{2^{\prime \prime}} 3^{\prime \prime}=\mathrm{J}_{5^{\prime \prime}, 6^{\prime \prime}}=8.8 \mathrm{~Hz}\right), 8.44(\mathrm{~s}, 1 \mathrm{H}, 8-\mathrm{H})$, 8.58 (d, 2H, 3", 5"'-H). Anal. Calcd for $\mathrm{C}_{16} \mathrm{H}_{16} \mathrm{~N}_{6} \mathrm{O}_{5}: \mathrm{C}, 51.61$; $\mathrm{H}, 4.33$; N, 22.57. Found: C, 51.60; H, 4.34; N, 22.30 .

2'-Deoxy-2-(m-nitrophenyl)-adenosine $(\mathbf{1 5 m})$. A mixture of 13 (200 $\mathrm{mg}, 0.43 \mathrm{mmol}$ ) and $m$-nitrobenzonitrile $(400 \mathrm{mg}, 2.7$ $\mathrm{mmol}$ ) in ethanolic ammonia (saturated at $0^{\circ} \mathrm{C}, 20 \mathrm{ml}$ ) in a sealed tube was heated at $170^{\circ} \mathrm{C}$ for $7 \mathrm{~h}$. The mixture was evaporated to dryness and the residue was purified over a silica gel column eluted with chloroform containing $1 \%$ ethanol to give $14 \mathrm{~m}(127$ $\mathrm{mg}, 48 \%$ as a foam), mass $\mathrm{m} / \mathrm{z}: 614\left(\mathrm{M}^{+}\right)$. Compound $14 \mathrm{~m}$ (120 mg, $0.195 \mathrm{mmol}$ ) was dissolved in dry tetrahydrofuran (5 $\mathrm{ml}$ ), which was treated with $1 \mathrm{M}$ tetrahydrofuran solution of tetrabutylammonium fluoride $(0.5 \mathrm{ml})$ for $30 \mathrm{~min}$ at room temperature. The mixture was neutralized with acetic acid and evaporated to dryness. The residue was crystallized from aqueous methanol to afford $15 \mathrm{~m}$ (70 $\mathrm{mg}, 92 \%$ as a hydrate); $\mathrm{mp}$. $150-153^{\circ} \mathrm{C}$. Mass $\mathrm{m} / \mathrm{z}: 372\left(\mathrm{M}^{+}\right)$. ' $\mathrm{H}-\mathrm{NMR}\left(\mathrm{DMSO}-\mathrm{d}_{6}+\right.$ $\mathrm{D}_{2} \mathrm{O}$ ): $\delta 2.35$ (ddd, $1 \mathrm{H}, 2^{\prime}-\mathrm{H}, \mathrm{J}_{1^{\prime}, 2^{\prime}}=6.0 \mathrm{~Hz}, \mathrm{~J}_{2^{\prime}, 3^{\prime}}=3.3 \mathrm{~Hz}$, $\mathrm{J}_{2^{\prime}, 2^{\prime}}=13.2 \mathrm{~Hz}$ ), 2.80 (ddd, $1 \mathrm{H}, 2^{\prime \prime}-\mathrm{H}, \mathrm{J}_{1^{\prime}, 2^{\prime \prime}}=7.1 \mathrm{~Hz}, \mathrm{~J}_{2^{\prime \prime}} .^{\prime}$ $=6.1 \mathrm{~Hz}), 3.53\left(\mathrm{dd}, 1 \mathrm{H}, 5^{\prime}-\mathrm{H}, \mathrm{J}_{4^{\prime}}, 5^{\prime}=4.9 \mathrm{~Hz}, \mathrm{~J}_{5^{\prime}} .^{\prime \prime}=11.5\right.$ $\mathrm{Hz}$ ), $3.63\left(\mathrm{dd}, 1 \mathrm{H}, 5^{\prime \prime}-\mathrm{H}, \mathrm{J}_{4^{\prime}} 5^{\prime \prime}=4.9 \mathrm{~Hz}\right), 3.90\left(\mathrm{~m}, 1 \mathrm{H}, 4^{\prime}-\mathrm{H}\right)$, 4.46 (dd, 1H, 3'-H), 6.47 (dd, $\left.1 \mathrm{H}, 1^{\prime}-\mathrm{H}\right), 7.79\left(\mathrm{t}, 1 \mathrm{H}, 5^{\prime \prime}-\mathrm{H}\right.$, $\left.\mathrm{J}_{4^{\prime \prime}, 5^{\prime \prime}}=\mathrm{J}_{5^{\prime \prime}, 6^{\prime \prime}}=8.2 \mathrm{~Hz}\right), 8.30\left(\mathrm{~m}, 1 \mathrm{H}, 6^{\prime \prime}-\mathrm{H}\right), 8.42(\mathrm{~s}, 1 \mathrm{H}$, 8-H), $8.76\left(\mathrm{~d}, 1 \mathrm{H}, 4^{\prime \prime}-\mathrm{H}\right), 9.13\left(\mathrm{t}, 1 \mathrm{H}, 2^{\prime \prime}-\mathrm{H}\right)$. Anal. Calcd for $\mathrm{C}_{16} \mathrm{H}_{16} \mathrm{~N}_{6} \mathrm{O}_{5} \cdot \mathrm{H}_{2} \mathrm{O}: \mathrm{C}, 49.23 ; \mathrm{H}, 4.65 ; \mathrm{N}, 21.52$. Found: $\mathrm{C}$, 49.36; H, 4.57; N, 21.32.

\section{Mutation assay}

The Ames assay was performed with the preincubation technique ${ }^{16}$. The $9000 \times \mathrm{g}$ supernatant of liver homogenate (S9) was prepared from rats induced with polychlorinated biphenyl (PCB-54, Tokyo Kasei Chemicals; Cl content, ca. 54\%). For metabolic activation, $S 9$ mix containing $50 \mu \mathrm{l}$ (per plate) of this S9 and supplementary coenzymes was used. In all the mutation assays, each datum represents a mean in two plates. For each value, the background revertant score had been subtracted.

\section{Assay for mutagenic activity in FM3A cells}

Mouse mammary carcinoma cell line FM3A, subclone F28-7, was maintained at $37^{\circ} \mathrm{C}$ under $5 \% \mathrm{CO}_{2}$ in suspension culture in ES medium (Nissui Pharmaceutical Co., Ltd., Tokyo) supplemented with $10 \%$ heat-inactivated fetal bovine serum (FBS). Mutation to ouabain resistance was measured. Logarithmically growing cells were inoculated into the medium at a density of $5 \times 10^{4}$ cells $/ \mathrm{ml}$. The culture was incubated at $37^{\circ} \mathrm{C}$ for 1 day; then 2 -( $p$-nitrophenyl)-2'-deoxyadenosine (15p) was added and the cell suspension was incubated for $24 \mathrm{~h}$. The medium was changed, and the cells were cultured for additional 3 days for expression. Then the cells were inoculated into plates of soft-agarose consisting of $0.375 \%$ Nobel agar (Difco Laboratories, Detroit, Mich.) and 0.125\% Agarose 1600 (Wako Pure Chemical Industries, Ltd., Osaka) in ES medium supplemented with $10 \%$ FBS. The number of cells inoculated into each dish was $1 \times 10^{6}$. Ouabain had been added in a $2 \mathrm{mM}$ concentration to the agar-agarose layers on the plates. Colonyforming ability was measured as follows. The cells, which had been cultured for additional 3 days for expression, were diluted with fresh ES medium to give a final density of $500 \mathrm{cells} / \mathrm{ml}$. Two hundred $\mu \mathrm{l}$ of the cell suspension was inoculated onto the surface of agar-agarose plate that did not contain ouabain. The plates were cultured for 10 days, and the colonies formed were counted.

$\mathrm{ED}_{50}$ value refers to the concentration of drug necessary to inhibit the growth rate of cells b $50 \%$ of the control, as determined by the procedure described before ${ }^{17}$.

\section{REFERENCES}

1. This paper constitutes part 91 of 'Nucleosides and Nucleotides'; part 90 : Yoshimura,Y., Matsuda,A. and Ueda, T. (1990) Chem. Pharm. Bull. in press.

2. Freese,E. (1959) J. Mol. Biol. 1, 87-105.

3. Popowska,E. and Janion,C. (1975) Nucl. Acids Res. 2, 1143-1151.

4. Popowska,E. and Janion,C. (1984) Biochem. Biophy. Res. Comm. 56, $459-466$.

5. Janion,C. (1978) Mutation Res. 56, 225-234.

6. Negishi,K., Harada,C., Ohara,Y., Oohara,K., Nitta,N. and Hayatsu,H. (1983) Nucl. Acids Res. 11, 5224-5233.

7. Chu,B.C.F., Brown,D.M. and Burdon,M.G. (1974) Mutation Res. 23, $267-273$.

8. Ames,B.N., McCann,J. and Yamasakj,E. (1975) Mutation Res. 31, $347-364$.

9. Matsuda,A., Satoh,K., Tanaka,H. and Miyasaka,T. (1984) Synthesis, $963-965$.

10. Matsuda,A., Ueda,T., Ohara,Y., Satake,H., Negishi,K., Wataya,A. and Hayatsu,H. (1986) Nucl. Acids Res., Symp. Ser. 17, 141-143.

11. Matsuda,A. and Ueda,T. (1987) Nucleosides \& Nucleotides, 6, 85-94.

12. Marumoto,R., Yoshioka,Y., Miyashta,O., Shima,S., Imai,K., Kawazoe,K. and Honjo,M. (1985) Chem. Pharm. Bull. 23, $759-774$.

13. Markiewicz,W.T. (1979) J. Chem. Res. Synop. 24-?.

14. Barton,D.H.R. and Subramanian,R. (1977) J. Chem. Soc., Perkin Trans. 1, 1718-?.

15. Takahashi,M., Nishizawa,M., Negishi,K., Hanaoka,F., Yamada,M. and Hayatsu,H. (1988) Mol. Cell Biol. 8, 347-352.

16. Yahagi,T., Nagao,M., Seino,Y., Matsushima,T., Sugimura,T. and Okada,M. (1977) Mutation Res. 48, $121-129$.

17. Yoshioka,A., Tanaka,S., Hiraoka,O., Koyama, Y., Hirota, Y., Ayusawa,D Seno,T., Garret, C. and Wataya,Y. (1987). J. Biol. Chem. 262, 8235-8241. 